\title{
Pathophysiology of Concurrent Trauma and Exsanguination
}

\section{EI Rasheid Zakaria ${ }^{1 *}$ and Bellal Joseph ${ }^{1}$}

Department of Surgery, The University of Arizona, USA

*Corresponding author: El Rasheid Zakaria, Department of Surgery, The University of Arizona, USA, Tel: +520- 626-9010; E-mail: drelzak@surgery.arizona.edu Received date: September 26, 2017; Accepted date: September 26, 2017; Published date: September 29, 2017

Copyright: (2017 Zakaria ER, et al. This is an open-access article distributed under the terms of the Creative Commons Attribution License, which permits unrestricted use, distribution, and reproduction in any medium, provided the original author and source are credite.

\section{Editorial}

Trauma continues to remain the leading cause of morbidity and mortality in the developed countries [1]. Hemorrhage is the second most common cause of death after trauma, only outnumbered by traumatic brain injury [2]. Exsanguinating hemorrhage is the most common cause of mortality in the first hour of arrival to a trauma center and accounts for almost half of deaths in the first $24 \mathrm{~h}[3,4]$. In addition, about $20-40 \%$ of trauma deaths that occur after hospital admission usually involve massive hemorrhage, in which death is potentially preventable [5]. Although the resuscitation protocols and management strategies for resuscitation of patients with exsanguinating hemorrhage have evolved in the past two decades, mortality among these patients remains high.

The type and site of injury are detrimental to the pathophysiology and to the outcome of traumatic exsanguination. While a penetrating injury rapidly provokes hypovolemia and its sequel, a blunt trauma and bleeding from extensive tissue damage triggers a strong inflammatory response. Trauma to the head or to the pelvis is associated with significant mortality and morbidity particularly when accompanied by progressive or uncompressible hemorrhage. The pathophysiology of traumatic exsanguination encompasses four major pillars: I) Profound depletions of cellular energy stores; II) Progressive end-organ vasoconstriction and hypo-perfusion; III) Exaggerated systemic inflammatory response (SIR); and IV) Obligatory fluid shifts and failure of early fluid mobilization. These four pillars are interdependent and interact in a vicious circle pattern to determine the outcome from a traumatic exsanguination.

Traumatic hemorrhage triggers a central neuroendocrine response that is characterized by an increased sympathetic drive and catecholamine surge. This compensatory mechanism aims to the redistribution of an already falling cardiac output away from large vascular beds like the splanchnic region, skin and skeletal muscle, to support central organs that are more vulnerable to ischemia and hypoxia. Although ischemia and hypoxia are not identical events at the biological and pathological level, both share a critical effect: a decreased supply of oxygen, resulting in a failure of cellular cytosolic energy (adenosine-5'-triphosphate, ATP) generation by oxidative phosphorylation with the following sequel: i) Profound depletions of cellular cytosolic energy stores [6,7]; ii) All energy-dependent processes, including active membrane transport, cell volume regulatory mechanisms and the endothelium-dependent control of vascular tone in the microcirculation are compromised; iii) Osmotic imbalances are caused by the failure to maintain normal ion gradients leading to paradoxical cellular edema [8-10], and similar abnormalities afflict membrane-bounded organelles including lysosomes and mitochondria; iv) Glycolysis is stimulated from the low energy charge (anaerobic), with the resultant accumulation of lactic acid, which decreases the $\mathrm{pH}$ of the ischemic tissue; and v) Both the plasma membrane and the organellar membranes become leaky because of osmotic stress and increased acidity. Lysosomal enzymes are released, and in their acidified environment, they attack cellular proteins, glycoproteins, glycolipids, phosphate esters, and other substrates to cause tissue injury.

Blood flow distributions among the body's various vascular circuits are typically altered in traumatic exsanguinations. This alteration occurs much in accordance with the exsanguination-induced changes in the local pressure head and the vascular resistance within the vascular circuit. By using direct or indirect methods of blood flow measurement techniques in different classes of traumatic exsanguinations, numerous studies have demonstrated decreased blood flow in the vascular circuits of different organs [11-16]. The decrease in organ blood flow during exsanguination constitutes a relative ischemia that is almost always associated with hypoxia as the blood flow delivery of $\mathrm{O}_{2}$ decreases, and the $\mathrm{O}_{2}$ extraction and utilization is also compromised by the inherent poor capillary filling $[17,18]$. In traumatic exsanguination, many factors impede capillary filling to drastically reduce the effective capillary surface area available for $\mathrm{O}_{2}$ and nutrients exchange. Among these factors are vasomotion and the vascular tone, the vascular endothelium status, blood rheology and the pressure drop that directly modulate the pre-to-post capillary resistance ratio that determine capillary filling, and hence, tissue perfusion. The end-organ progressive vasoconstriction and hypoperfusion elicited during exsanguination primes the vascular endothelium and the circulating white blood cells and platelets to trigger a systemic inflammatory response (SIR) [19]. SIR also originates from the damaged tissue that results from the traumatic injury. This controlled host-response is mediated by both proinflammatory as well as by anti-inflammatory cytokines, chemokines, lipid mediators, vasoactive peptides, and by enzymatic systems to orchestrate an acute response to tissue damage and a delayed tissue repair process $[20,21]$.

Obligatory fluids shifts occur during traumatic exsanguination due to the cellular ionic disequilibrium, and to the perturbations of the physiologic imbalance of the Starling forces that govern the transcapillary fluid exchange $[9,10]$. Several mechanisms contribute to the cellular swelling. Depletion of cellular energy stores during traumatic exsanguination impairs the energy-dependent $\mathrm{Na}^{+}-\mathrm{K}^{+}$-ATPase function to eventually leads to $\mathrm{Na}^{+}$accumulation and cellular swelling [22]. Cellular swelling is also favored by the accumulation of extracellular $\mathrm{K}^{+}$concentration, lactic academia and as seen in the brain by glutamate, which stimulates cationic receptors and subsequent accumulation of $\mathrm{Na}^{+}$, depolarization and uptake of $\mathrm{Cl}^{-}$[23-26]. Remarkable $\mathrm{Na}^{+} / \mathrm{H}^{+}$exchanger-mediated endothelial cell swelling was observed in intestinal capillaries in hemorrhagic shock [8-10]. This is presumably due to cytosolic acidosis from the increased $\mathrm{PCO}_{2}$ and the lactic acid build up from the anaerobic glycolysis, and from the effects of cytosolic acidification on the cell volume regulatory mechanisms 
$[27,28]$. As reviewed elsewhere, the cell volume changes described herein markedly influence a wide variety of genes (for review see [29], particularly aldose reductase and the $\mathrm{Na}^{+}$-coupled transport systems for proteins such as inositol, betaine, taurine and amino acids. These proteins serve cellular accumulation of osmolytes to restore cell volume constancy [29].

In summary, the pathophysiology of concurrent trauma and exsanguinations consists of complex interactions at the molecular, cellular, and tissue levels of dysfunctions created by a cytosolic energy failure and sustained by ischemic hypoxia. These dysfunctions interact with each other in a cause-effect relationship and a vicious circle pattern to finally result in death from cardio-circulatory arrest.

\section{References}

1. Rhee P, Joseph B, Pandit V, Aziz H, Vercruysse G, et al. (2014) Increasing trauma deaths in the United States. Ann Surg 260: 13-21.

2. Sobrino J, Shafi S (2013) Timing and causes of death after injuries. Proc (Bayl Univ Med Cent) 26: 120-123.

3. Brohi K, Singh J, Heron M, Coats T (2003) Acute traumatic coagulopathy. J Trauma 54: 1127-1130.

4. MacLeod JB, Lynn M, McKenney MG, Cohn SM, Murtha M (2003) Early coagulopathy predicts mortality in trauma. J Trauma 55: 39-44.

5. Tisherman SA, Schmicker RH, Brasel KJ, Bulger EM, Kerby JD, et al. (2015) Detailed description of all deaths in both the shock and traumatic brain injury hypertonic saline trials of the Resuscitation Outcomes Consortium. Ann Surg 261: 586-90.

6. Chaudry IH, Baue A (1976) Alterations in adenosine 3',5'--monophosphate levels in hemorrhagic shock. Surg Forum 27: 51-53.

7. Chaudry IH, Baue AE (1977) Depletion of replenishment of cellular cyclic adenosine monophosphate in hemorrhagic shock. Surg Gynecol Obstet 145: 877-881.

8. Mazzoni MC, Borgstrom P, Intaglietta M, Arfors KE (1989) Lumenal narrowing and endothelial cell swelling in skeletal muscle capillaries during hemorrhagic shock. Circ Shock 29: 27-39.

9. Zakaria ER, Li N, Matheson PJ, Garrison RN (2007) Cellular edema regulates tissue capillary perfusion after hemorrhage resuscitation. Surgery 142: 487-496.

10. Zakaria ER, Matheson PJ, Flessner MF, Garrison RN (2008) Hemorrhagic shock and resuscitation-mediated tissue water distribution is normalized by adjunctive peritoneal resuscitation. J Am Coll Surg 206: 970-980.

11. Cavus E, Meybohm P, Doerges V, Hugo HH, Steinfath M, et al. (2009) Cerebral effects of three resuscitation protocols in uncontrolled haemorrhagic shock: a randomised controlled experimental study. Resuscitation 80: 567-572.

12. Deitch EA, Chu H, Xu dZ (2008) Organ blood flow and the central hemodynamic response are better preserved in female, as opposed to the male rats, after trauma-hemorrhagic shock. J Trauma 65: 566-572.
13. Flynn WJ Jr, Gosche JR, Garrison RN (1992) Intestinal blood flow is restored with glutamine or glucose suffusion after haemorrhage. J Surg Res 52: 499-504.

14. Fruchterman TM, Spain DA, Matheson PJ, Martin AW, Wilson MA, et al. (1998) Small intestinal production of nitric oxide is decreased following resuscitated hemorrhage. J Surg Res 80: 102-109.

15. Hurt RT, Zakaria ER, Matheson PJ, Cobb ME, Parker JR, et al. (2009) Hemorrhage-induced hepatic injury and hypoperfusion can be prevented by direct peritoneal resuscitation. J Gastrointest Surg 13: 587-594.

16. Zakaria ER, Spain DA, Harris PD, Garrison RN (2002) Resuscitation regimens for hemorrhagic shock must contain blood. Shock 18: 567-573.

17. Zweifach BW (1974) Mechanisms of blood flow and fluid exchange in microvessels: hemorrhagic hypotension model. Anesthesiology 41: $157-168$.

18. Zweifach BW (1995) Microcirculatory homeostasis 1930-1990: insight into microcirculatory readjustments provided by studies on the peripheral circulatory insufficiency of the shock syndrome. Microcirculation 2: 245-51.

19. Zakaria ER, Campbell JE, Peyton JC, Garrison RN (2007) Postresuscitation tissue neutrophil infiltration is time-dependent and organ-specific. J Surg Res 143: 119-125.

20. Keel M, Trentz O (2005) Pathophysiology of polytrauma. Injury 36: 691-709.

21. Lenz A, Franklin GA, Cheadle WG (2007) Systemic inflammation after trauma. Injury 38: 1336-1345.

22. Jurkowitz-Alexander MS, Altschuld RA, Hohl CM, Johnson JD, McDonald JS, et al. (1992) Cell swelling, blebbing, and death are dependent on ATP depletion and independent of calcium during chemical hypoxia in a glial cell line (ROC-1). J Neurochem 59: 344-352.

23. Choi DW, Rothman SM (1990) The role of glutamate neurotoxicity in hypoxic-ischemic neuronal death. Annu Rev Neurosci 13: 171-182.

24. Goldberg MP, Monyer H, Choi DW (1988) Hypoxic neuronal injury in vitro depends on extracellular glutamine. Neurosci Lett 94: 52-57.

25. Kempski O, Staub F, Schneider GH, Weigt H, Baethmann A (1992) Swelling of C6 glioma cells and astrocytes from glutamate, high $\mathrm{K}+$ concentrations or acidosis. Prog Brain Res 94: 69-75.

26. 26. Kempski O, Von RS, Weigt H, Staub F, Peters J, et al. (1991) Glial ion transport and volume control. Ann N Y Acad Sci 633: 306-317.

27. Lang F, Stehle T, Haussinger D (1989) Water, K+, H+, lactate and glucose fluxes during cell volume regulation in perfused rat liver. Pflugers Arch 413: 209-216.

28. MacLeod RJ, Hamilton JR (1996) Activation of $\mathrm{Na}+\mathrm{H}+$ exchange is required for regulatory volume decrease after modest "physiological" volume increases in jejunal villus epithelial cells. J Biol Chem 271: 23138-23145.

29. Lang F, Busch GL, Ritter M, Volkl H, Waldegger S, et al. (1998) Functional significance of cell volume regulatory mechanisms. Physiol Rev 78: 247-306. 